\title{
KUALITAS CITRA RADIOGRAFI BERDASARKAN VARIASI JEDA WAKTU PEMBACAAN CITRA PADA COMPUTED RADIOGRAPHY
}

\section{RADIOGRAPHIC IMAGE QUALITY IN VARIOUS IMAGE READING TIME DELAY IN COMPUTED RADIOGRAPHY}

\author{
Dartini $^{1)}$, Florentina Yunita Wulandari ${ }^{2)}$, Akhmad Haris Sulistiyadi ${ }^{3)}$ \\ ${ }^{1,3)}$ Health Polytechnics of Semarang-Indonesia \\ ${ }^{2)}$ Santo Borromeus Hospital, Bandung-Indonesia \\ e-mail: dartini.tini@gmail.com
}

\begin{abstract}
Background: Computed Radiography (CR) is imaging processor to digitize an image using imaging plate. Imaging plate can store latent image and should be read as soon as possible to avoid the loss of image quality. The longer storage time the lower image quality. This study aimed to determine the image quality in various image reading time delay.

Methods: This iresearch was quantitative research with experimental approach. 5 images were acquired using step wedge as an object with same exposure factors. The imaging plates were read in five different image reading time delay variations (no-delay, 2 hours, 4 hours, 6 hours, and 8 hours after eksposure). Contrast and density of each image were measured using $\lg \mathrm{M}$ and densitometer. Data were analyzed by comparing $\operatorname{lgM}$, density, and contrast of each image.

Result: The result showed that there were difference value in density, contrast, and lgM among no-delay, 2 hours, 4 hours, 6 hours, and 8 hours after eksposure images respectively. The average density were 0,$701 ; 0,776 ; 0,772 ; 0,798 ; 0,791$. The image contrast were 0,$88 ; 1,09$; 0,$88 ; 1,06 ; 1,02$. The $\operatorname{lgM}$ value were 2,$42 ; 2,24 ; 2,21 ; 2,20 ; 2,19$.

Conclusion: The image quality was decreased over reading time delay, the longer reading time delay the lower image quality. To obtain the best image quality, the imaging plate should be read as soon as possible.
\end{abstract}

Keywords: radiographic image quality, image reading time delay, imaging plate

\section{PENDAHULUAN}

Computed Radiography (CR) adalah proses digitalisasi gambar yang menggunakan photostimulable phospor atau imaging plate (IP) dalam akusisi data. Imaging Plate berbentuk seperti kaset radiografi dan di dalamnya terdapat lembaran phosphor yang memiliki kemampuan merekam yaitu dapat mempertahankan gambar laten pada jangka waktu tertentu, setelah terkena $X$-ray. Untuk membangkitkan bayangan laten tersebut, perlu dilakukan pembacaan citra (Image Reading) (Ballinger,2003).

Energi yang tersimpan dalam Imaging Plate menghilang dari waktu ke waktu sehingga harus dibaca sesegera mungkin setelah eksposi untuk menghindari kehilangan informasi gambar (Carter dan Veale, 2010). Gambar Laten akan kehilangan sekitar $25 \%$ energi dalam 8 jam, sehingga sangat penting untuk memproses kaset segera setelah paparan (Carlton dan Adler, 2001).

Kualitas radiograf merupakan kemampuan radiograf untuk menghasilkan kejelasan gambaran struktur anatomi yang baik pada sebuah radiograf. Kualitas radiograf yang tinggi diperlukan untuk menentukan diagnosa yang tepat oleh seorang dokter spesialis radiologi. Kualitas radiograf dapat dinilai dari densitas dan kontras (Bushong, 2001).

Dalam aplikasi di klinik, Image Reading biasanya dilakukan sekaligus, saat beberapa Imaging Plate telah terkumpul.Hal ini berpotensi menimbulkan penurunan kualitas radiograf yang dihasilkan
Penelitian ini bertujuan untuk menganalisis kualitas radiografi yang dihasilkan pada berbagai jeda pembacaan Imaging Plate.

\section{METODE}

Penelitian ini adalah jenis penelitian kuantitatif dengan pendekatan eksperimen. Lima citra dengan objek stepwedge (10 step) dengan faktor eksposi yang sama (50 kV dan $5 \mathrm{mAs})$. Jeda waktu pembacaan divariasikan dalam lima kelompok: tanpa jeda, 2 jam, 4 jam, 6 jam, dan 8 jam.

Pengukuran dilakukan terhadap $\operatorname{lgM}$, densitas, dan kontras dari citra-citra yang dihasilkan. $\operatorname{lgM}$ diketahui dari pengukuran terhadap citra pada workstation, sedangkan kontras dinilai dari perhitungan densitas tertinggi dan densitas terendah setelah citra dicetak. Analisis dilakukan secara deskriptif untuk melihat perbedaan pada masing-masing kelompok.

\section{HASIL}

Perbedaan kulaitas radiograf ditinjau dari nilai densitas dan kontras radiograf pada berbagai variasi waktu pembacaan Imaging Plate ditunjukkan pada tabel 1.

Tabel 1 menunjukkan densitas pada sepuluh step dengan rata-rata kelompok tanpa jeda, jeda 2 jam, jeda 4 jam, jeda 6 jam, dan jeda 8 jam secara berturut-turut adalah 0,$701 ; 0,776$; 0,$772 ; 0,798 ; 0,791$ 
Tabel 1. Nilai Densitas pada Berbagai Jeda Image Reading

\begin{tabular}{cccccc}
\hline \multirow{2}{*}{ Step } & \multicolumn{5}{c}{ Densitas Radiograf } \\
\cline { 2 - 6 } & $\begin{array}{c}\text { Tanpa } \\
\text { Jeda }\end{array}$ & $\begin{array}{c}\text { Jeda } 2 \\
\text { Jam }\end{array}$ & $\begin{array}{c}\text { Jeda 4 } \\
\text { Jam }\end{array}$ & $\begin{array}{c}\text { Jeda 6 } \\
\text { Jam }\end{array}$ & $\begin{array}{c}\text { Jeda } \\
8 \text { jam }\end{array}$ \\
\hline 1 & 1,32 & 1,51 & 1,34 & 1,50 & 1,47 \\
2 & 1.04 & 1,12 & 1,08 & 1,13 & 1,12 \\
3 & 0.82 & 0,96 & 0,95 & 0,98 & 0,96 \\
4 & 0,72 & 0,84 & 0,84 & 0,87 & 0,84 \\
5 & 0.65 & 0,77 & 0,74 & 0,77 & 0,76 \\
6 & 0,58 & 0,63 & 0,67 & 0,69 & 0,68 \\
7 & 0,51 & 0,55 & 0,61 & 0,60 & 0,60 \\
8 & 0,48 & 0,50 & 0,54 & 0,53 & 0,54 \\
9 & 0,45 & 0,46 & 0,49 & 0,48 & 0,49 \\
10 & 0,44 & 0,42 & 0,46 & 0,43 & 0,45 \\
\hline
\end{tabular}

Dari hasil pengukuran densitas, didapatkan nilai densitas yang naik turun dan lebih cenderung naik, hal ini tidak sesuai dengan Carter dan Veale (2010) yang menyatakan energi yang tersimpan dalam plat pencitraan menghilang dari waktu ke waktu, hal ini disebabkan oleh printer artifact yang menyebabkan garis putih-putih halus mungkin muncul pada gambar.

Tabel 2. Nilai Kontras pada Berbagai Jeda Image Reading

\begin{tabular}{ccccc}
\hline No & Radiograf & $\begin{array}{c}\text { Densitas } \\
\text { Maks }\end{array}$ & $\begin{array}{c}\text { Densitas } \\
\text { Min }\end{array}$ & Kontras \\
\hline 1 & Tanpa Jeda & 1,32 & 0,44 & 0,88 \\
2 & Jeda 2 Jam & 1,51 & 0,42 & 1,09 \\
3 & Jeda 4 Jam & 1,34 & 0,46 & 0,88 \\
4 & Jeda 6 Jam & 1,50 & 0,43 & 1,06 \\
5 & Jeda 8 Jam & 1,47 & 0,45 & 1,02 \\
\hline
\end{tabular}

Grafik 1. Nilai Kontras pada Berbagai Jeda Image Reading

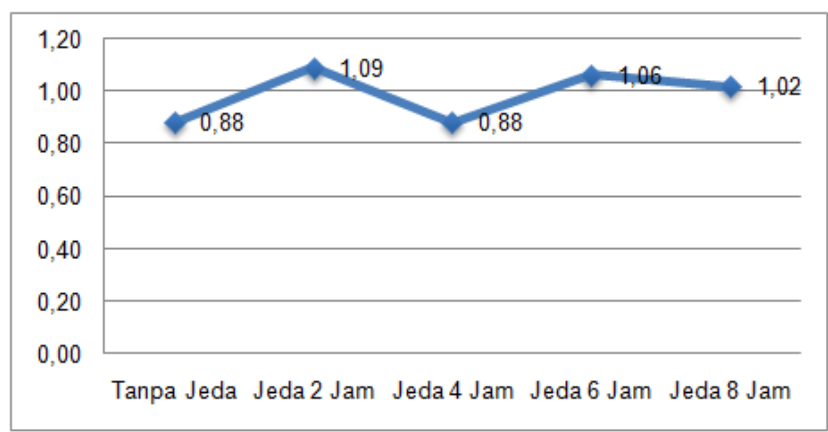

\section{DISKUSI}

Nilai kontras pada radiografi dengan jeda waktu Image Reading secara berturut-turut menghasilkan kontras rata-rata sebesar 0,88 (tanpa jeda);1,09 (jeda 2 jam); 0,88 (jeda 4 jam); 1,06 (jeda 6 jam); dan 1,02 (jeda 8 jam). Data tersebut menunjukkan bahwa perbedaan waktu pembacaan Imaging Plate membuat kontras radiograf berbeda. Nilai kontras cenderung naik pada jeda waktu yang semakin lama karena merupakan hasil pengurangan nilai densitas.

Nilai $\lg M$ pada berbagai jeda image reading ditunjukkan pada tabel 3 dan Grafik 2.

Tabel 3. Nilai lgM pada Berbagai Jeda Waktu Image Reading

\begin{tabular}{ccccc}
\hline Pengukuran & $\mathrm{A}$ & $\mathrm{B}$ & $\mathrm{C}$ & Rata-Rata \\
\hline Tanpa Jeda & 2,43 & 2,43 & 2,4 & 2,42 \\
Jeda 2 Jam & 2,16 & 2,28 & 2,27 & 2,24 \\
Jeda 4 Jam & 2,23 & 2,19 & 2,21 & 2,21 \\
Jeda 6 Jam & 2,19 & 2,18 & 2,22 & 2,20 \\
Jeda 8 Jam & 2,19 & 2,18 & 2,19 & 2,19 \\
\hline
\end{tabular}

Grafik 2. Nilai lgM

pada Berbagai Jeda Waktu Image Reading

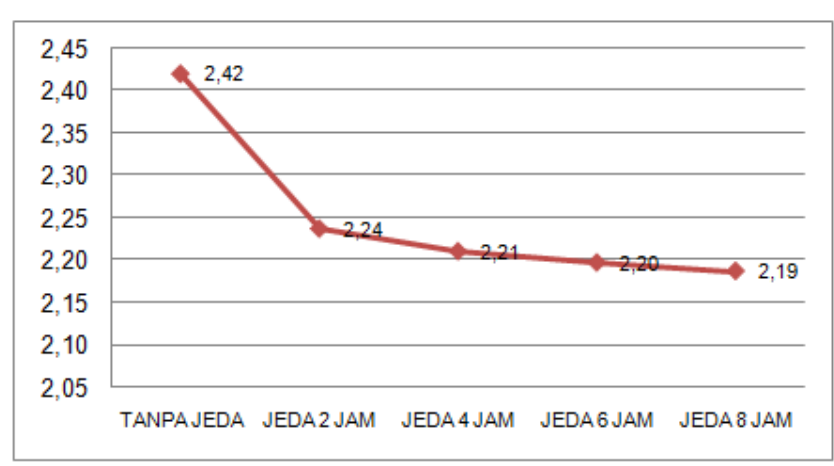

Nilai lgM pada citra dengan waktu Image Reading yang berbeda secara berturut-turut adalah 2,42 (tanpa jeda); 2,24 (jeda 2 jam); 2,21 (jeda 4 jam); 2,20 (jeda 6 jam); dan 2,19 (jeda 8 jam).

Tren tersebut menunjukkan adanya penurunan nilai $\operatorname{lgM}$ apabila jeda Image Reading semakin lama. Hal ini sesuai dengan Carter dan Veale (2010) yang menyebutkan energi yang tersimpan dalam plat pencitraan menghilang dari waktu ke waktu. Serta sesuai dengan Carlton dan Adler (2001) yang menyebutkan bahwa Gambar Laten akan kehilangan sekitar 25 persen energi dalam 8 jam, karena dari hasil pengukuran menunjukkan dari tanpa jeda sampai jeda 8 jam mengalami penurunan sebesar 9,05\%, sehingga sebaiknya waktu pembacaan Imaging Plate dilakukan segera setelah eksposi.

\section{SIMPULAN}

Densitas tidak dapat dijadikan sebagai parameter untuk mengukur kualitas radiograf pada Computed Radiography karena dipengaruhi oleh adanya printer artifact. 
Pada pengukuran $\lg \mathrm{M}$ mengalami penurunan karena energi yang tersimpan dalam plat pencitraan menghilang dari waktu ke waktu dan hasil pengukuran menunjukkan dari tanpa jeda sampai jeda 8 jam mengalami penurunan sebesar $9,05 \%$, sehingga sebaiknya waktu pembacaan Imaging Plate dilakukan segera setelah ekspose.

\section{DAFTAR PUSTAKA}

Bontrager, K. L. 2001. Textbook of Radiographic and Related Anatomy. Mosby Inc. Missouri.

Bushong, Steward C. 2001. Radiographic Science For Technologist Physics,Biology, and Protection. Amerika Serikat : Mosby inc.

Carlton, Ricard R, and Adler, Arlene M. 2001. Principles of Radiographic Imaging : An Art and A Science. Amerika Serikat : Delman

Carter,C,Veale,B. 2010. Digital Radiography and PACS. Mosby Missouri.

Frank, E. D, Ballinger, P.W. 2003. Radiographic Positions and Radiologic Prosedures, Mosby Inc., Missouri.

Papp, Jefray. 2006. Quality Management in the Imaging Science. United States of America.

Roberts, Derrick P and Smith, Nigel L. 1988. Radiographic Imaging. Churchill Livingstone. United State of America

Whitley, A. Stewart. 2005. Clark's Positioning in Radiography.Hodder Arnold.London.

Thomas Lehnert, Nagy N. Naguib, Hanns Ackermann, Christof Schomerus, Volkmar Jacobi, Joern O. Balzer dan Thomas J. Vog. 2011. Novel, Portable, Cassette-Sized, and Wireless Flat-Panel Digital Radiography System: Initial Workflow Results Versus Computed Radiography. Diakses pada tanggal 11 Februari 2014 darihttp://www.ajronline.org /doi /full/10.2214/AJR.10.5505

Reiner, E Siegel, T McLaurin, S Pomerantz, R Allman, J R Hebel, S Fritz and $\mathrm{Z}$ Protopapas. 1996. Evaluation of soft-tissue foreign bodies: comparing conventional plain film radiography, computed radiography printed on film, and computed radiography displayed on a computer workstation. Diakses pada tanggal 11 Februari 2014 dari http://www.ajronline.org/doi/full/10.2214/AJR.10.5505 